\title{
LEGAL NATURE OF EMAILS: A COMPARATIVE PERSPECTIVE
}

\begin{abstract}
EDINA HARBINJA ${ }^{\dagger}$
ABSTRACT

There is currently a conflict between laws and the market in their treatment of email. Laws mandate that emails are not protected as property unless copyrightable or protected by another legal mechanism. But the market suggests that emails are user-owned property without further qualification. Moreover, the nature of email is treated slightly differently between the U.S. and U.K. legal regimes. While the current legal regimes applicable to email in the U.K. and U.S. are reasonable, legal harmonization within these systems, and with the service provider market, should be achieved.
\end{abstract}

\section{INTRODUCTION}

Email is widely known as an electronic system for exchange of messages over the Internet. However, "email" commonly refers to individual electronic messages, and usually only to the text of the messages and their attachments. ${ }^{1}$ Email "accounts," on the other hand, can be analogized to the paper on which letters are written. ${ }^{2}$ Along this line, accounts may be explained as some form of "physical" representation of email, enabling and regulating access to the content, just as papers are physical representation of letters and define access to their content.

According to the terms of service of Google, the leading email service provider, the content that users "upload, submit, store, send or receive" is owned by the users. ${ }^{3}$ Most service providers, however, claim a

\footnotetext{
${ }^{\dagger}$ Senior Lecturer in Law, University of Hertfordshire. This work was supported by the Horizon Digital Economy Hub, Nottingham; forms part of the work program of the Research Councils UK funded Centre for Creativity, Regulation, Enterprise and Technology (CREATe); also supported by The University of Strathclyde King Hugh Fund; The Clark Foundation.

${ }^{1}$ See Derek Hansen et.al., Analyzing Social Media Networks with NODEXL: INSIGHTS FROM A CONNECTED WORLD 106 (2010); Jianqiang Shen et al., A Comparison Study of User Behavior on Facebook and Gmail, 29 COMPUTERS IN HUMAN BEHAVIOR 2650, 2650-55 (2013).

2 Jason Mazzone, Facebook's Afterlife, 90 N.C. L. REV. 1643, 1651 (2012) (referring to Grigsby v. Breckenridge, 65 Ky. (2 Bush) 480 (1867)).

3 Google Terms of Service, Google (Apr. 14, 2014), http://www.google.com/intl/en-GB/policies/terms/. See also Yahoo Terms of
} 
worldwide, royalty free and non-exclusive license to use and perform other actions with that content. ${ }^{4}$ There are some minor differences, however. When it comes to ownership, Google refers to all user content whereas Microsoft refers only to some user content. ${ }^{5}$ As for terms of service, Google's and Microsoft's terms apply to all content, whereas Yahoo's terms apply only to "photos, graphics, audio or video." ${ }^{\prime 6}$ For all other content that users "submit or make available for inclusion on publicly accessible areas of the Yahoo Services," Y Yahoo retains "[a] worldwide, royalty-free, non-exclusive, perpetual, irrevocable, and fully sublicensable license." ${ }^{\prime 8}$ Emails do not seem to belong to any of those categories. Thus, the general provision allowing users to retain ownership appears to apply to email content.

But does U.S. and U.K. law agree that users own this email content as property? To answer this question, this note will focus on the legal nature of emails and accounts, represented by their content. ${ }^{9}$ First, it will focus on the state of the law with respect to copyright issues, which spans users' rights to control the original content of emails they create. Then, it will focus on the state of the law with respect to users owning information, personal data, and related data contained in their emails as

Service, YAHOO! (Jan. 20, 2014), https://info.yahoo.com/legal/eu/yahoo/utos/en$\mathrm{gb} /$.

${ }^{4} I d$.

5 Microsoft Services Agreement, Microsoft (June 4, 2015), http://windows.microsoft.com/en-gb/windows-live/microsoft-services-

agreement (" $[\mathrm{Y}]$ our communications with others; postings or feedback submitted by you to Microsoft via the Services; and the files, photos, documents, audio, digital works, and videos that you upload, store or share through the Services.").

6 Yahoo Terms of Service, YAHOO! II 9.2 (Jan. 20, 2014), https://info.yahoo.com/legal/eu/yahoo/utos/en-gb/.

${ }^{7}$ Id. II 9.4

${ }^{8}$ Id.

9 Edwards and Harbinja define digital assets "widely and not exclusively to include a huge range of intangible information goods associated with the online or digital world", giving examples of different digital assets. Lillian Edwards \& Edina Harbinja, What Happens to My Facebook Profile When I Die? Legal Issues Around Transmission of Digital Assets on Death, in DigiTAL LEGACY AND InTERACTION: POST-MorTEM ISSUES 115, 115-44 (Cristiano Maciel \& Vinicius Carvalho Pereira eds., 2013). For other definitions see Naomi Cahn, Postmortem Life On-Line, 25 PROB. \& PROP. 36, 36-37 (2011); Jamie Hopkins, Afterlife in the Cloud: Managing a Digital Estate, 5 HASTINGS SCI. \& TECH L.J. 210, 211(2013); Delia Băbeanu et al., Strategic Outlines: Between Value and Digital Assets Management, 11 ANNALES UNIVERSITATIS APULENSIS SERIES OECONOMICA 318, 319 (2009). 
property. ${ }^{10}$ The analysis will be based on U.K.-mainly English - and U.S. law. Finally, this note will evaluate western property theories and determine whether they are applicable to email information.

\section{CASE LAW: A BACKGROUND}

The U.S. and the European media widely reported the U.S. case of In Re Ellsworth as a clarification on the nature of email. ${ }^{11}$ The case, however, did not clarify the issue of the nature of email at all. It perhaps even complicated the matter further. In the case, Yahoo, an email provider, initially refused to give the family of a U.S. Marine Justin Ellsworth, who was killed in action in Iraq, access to his email account. Yahoo referred to their terms of service, which were designed to protect the privacy of the user by forbidding access to third parties upon death of the user. ${ }^{12}$ Yahoo also argued that the U.S. Electronic Communications Privacy Act of 1986 prohibited them from disclosing a user's personal communications without a court order. ${ }^{13}$ The family argued that as his heirs, they should be able to access the entire account, including his sent and received emails, as his last words. Yahoo, on the other hand, had a non-survivorship policy. What is more, Ellsworth's account could have been deleted, contrary to the wishes of his family. The judge in this case allowed Yahoo to enforce their privacy policy and did not order transfer of the account username and

${ }^{10}$ See Directive 95/46/EC, of the European Parliament and of the Council of 24 October 1995 on the Protection of Individuals With Regard to the Processing of Personal Data and on the Free Movement of Such Data, 1995 O.J. (L 281) 31 art. 2(a).

${ }^{11}$ In re Ellsworth, No. 2005-296, 651-DE (Mich. Prob. Ct. 2005). See also, e.g., Who Owns Your E-mails?, BBC NeWs (Jan. 11, 2005), http:// news.bbc.co.uk/1/hi/magazine/4164669.stm; Paul Sancya, Yahoo Will Give Family Slain Marine's E-Mail Account, USA TODAY (Apr. 21, 2005), http://usatoday30.usatoday.com/tech/news/2005-04-21-marine-e-

mail_x.htm?POE=TECISVA; Tress Baldas, Slain Soldier's E-Mail Spurs Legal Debate: Ownership of Deceased's Messages at Crux of Issue, 27 NAT'L L.J. 10 (2005).

12 Yahoo Terms of Service, YAHOO! (Jan. 20, 2014), https://policies.yahoo.com/ie/en/yahoo/terms/utos/index.htm ("No Right of Survivorship and Non-Transferability. Your Yahoo account is non-transferable and any rights to your Yahoo ID or contents within your account will be cancelled upon your death. If we receive a copy of a death certificate, the relevant account may be cancelled and all its contents permanently deleted.").

${ }^{13}$ See Ada Kulesza, What Happens to Your Facebook Account When You Die?, LAWYERS.COM (Feb. 3, 2012), http://blogs.lawyers.com/2012/02/what-happensto-facebook-account-when-you-die/; Justin Atwater, Who Owns Email? Do You Have the Right to Decide the Disposition of Your Private Digital Life?, 2006 UTAH L. REV. 397, 401 (2006). 
password. Rather, he ordered Yahoo to provide the family with a CD containing copies of the emails in the account. ${ }^{14}$

What legal regime could explain this result? One interpretation is that Yahoo owned the copies of the emails stored on their servers, but were required by the court order to make the information in them available. ${ }^{15}$ For this justification can be found in the traditional division of rights in letters. Yahoo would own the emails - as a physical representation - but the deceased, as author, would own the copyright, transferred subsequently to the heirs. A second interpretation is to regard the deceased as the owner of the emails while alive, which then could be transmitted to the heirs of the deceased upon death. ${ }^{16}$ This interpretation is less likely, as the court would then have regarded the rights of the heirs as overriding the terms and conditions entered into by the deceased, ordering full access to the account. The court only ordered Yahoo to disclose the contents of the emails, though. Thus, it can be concluded that Yahoo was found to have ownership of the account, and the heirs' were found to have a right to access the content of the emails. But the court refrained from establishing principles in relation to property, intellectual or otherwise, in email content. Instead, it focused on privacy issues. ${ }^{17}$ Alas, the case left many questions open and provided little guidance that could be applied subsequently.

English law has been slightly more specific on the issue. In Fairstar Heavy Transport N.V. v. Adkins, Justice Edwards-Stuart concluded that emails could not be considered property. ${ }^{18}$ The case concerned a commercial dispute between an ex-employee and the new owners of a company. The dispute involved important emails sent to the ex-employee, which had been forwarded to his private email address and deleted from the company server. The company claimed that the emails should be declared the property of the company. Referring to previous case law relating to the status of information as property in the context of letters,${ }^{19}$ Justice Edwards-Stuart identified a distinction between a physical

${ }^{14}$ See Soldier's Kin to Get Access to His Emails, JustinELlsworth.NET (Apr. 21, 2005), http://www.justinellsworth.net/email/ap-apr05.htm.

${ }^{15}$ Edwards \& Harbinja, supra note 9, at 123-25.

${ }^{16}$ See id. at $123-24$.

${ }^{17}$ See generally Jonathan J. Darrow \& Gerald R. Ferrera, Who Owns a Decedent's E-Mails: Inheritable Probate Assets or Property of the Network?, 10 N.Y.U. J. LEGIS. \& PUB. POL'Y 281, 313-314 (2007); Atwater, supra note 12, at 399.

${ }^{18}$ Fairstar Heavy Transport NV v. Adkins, [2012] EWHC (TCC) 2952 [58] (Eng). See also Edwards \& Harbinja, supra note 9, at 120.

${ }^{19}$ See, e.g., Philip v. Pennell [1907] 2 Ch 577 (Eng.); Boardman v. Phipps [1967] 2 AC 46 (Eng.); Coogan v. News Group Newspapers Ltd. [2012] EWCA (Civ) 48 (Eng.); Force India Formula One Team v. 1 Malaysian Racing Team [2012] EWHC (Ch) 616 (Eng.). 
medium and the information it carried, noting that only a physical objectpaper - can be owned. ${ }^{20}$ The judge concluded that "[t]here are no compelling practical reasons that support the existence of a proprietary right-indeed, practical considerations militate against it." 21

Subsequently, the Court of Appeal recognized the difficulties that property in information encounters conceptually. The court, however, wisely avoided this discussion and decided that the real issue in the case was that of agency. The first instance decision, therefore, provides some guidance and an indication that in black-letter English law, emails are not considered property. This, at a first glance, makes it clear that we need to consider some other legal mechanisms in order to define the nature of emails, such as copyright, contracts, or privacy.

\section{COPYRIGHT IN EMAILS}

Emails are perceived mainly as works ${ }^{22}$ created by their authors, the email senders. Therefore, copyright appears to be one of the most

${ }^{20}$ Fairstar EWHC (TCC) 2952 [43] ("I disagree; there is or may be an important distinction between the physical object which carries the information - for example, a letter - and the information which that object conveys. A letter, which consists of paper together with the ink of the writing which is on it, is clearly a physical object that can be owned. However, it does not follow from this that the information which the letter conveys is also property that is capable of being the subject of a proprietary claim (for this purpose I leave aside the possibility of any claim arising out of copyright in respect of the contents of the letter)."; id. II 58 ("In my judgment it is clear that the preponderance of authority points strongly against there being any proprietary right in the content of information, and this must apply to the content of an e-mail, although I would not go so far as to say that this is now settled law. Some of the observations that I have quoted are in terms that are less than emphatic and, of course, the two contrary views in Boardman v Phipps are entitled to significant weight."). See also Boardman 2 AC 46 [127]; Douglas v. Hello! Ltd. [2008] 1 AC 1 [275] (Eng.) ("That observation still holds good in that information, even if it is confidential, cannot properly be regarded as a form of property."); Force India EWHC (Ch) 616 [376].

${ }^{21}$ Fairstar EWHC (TCC) 2952 [69]. Justice Edwards-Stuart's analysis illustrates five different scenarios that would be the potential results if an email was considered capable of being property. These scenarios will be discussed more in section II.B.1.ii.

${ }^{22}$ This note focuses on the unpublished content of emails, either in the form of an attachment or as the text of the message, rather than content of emails that has been published elsewhere. Although not published elsewhere, this note argues these previously unpublished works should nevertheless be protected by copyright as literary or musical works. See Copyright, Designs and Patents Act, 1988, c. 48, § 3 (U.K.); 17 U.S.C. $§ 101$ (2012). Additionally, the definition of "published" encompasses Internet publications. See, e.g., Copyright, Designs and Patents Act, 1988, c. 48, § 175 (U.K.); 17 U.S.C. § 101 (2012); Berne Convention for the Protection of Literary and Artistic Works art. 3, Sept. 9, 1886, 25 U.S.T. 
obvious answers when determining the legal nature of emails. Historically, copyright protection of unpublished works was perpetual in the common law jurisdictions, the United Kingdom and United States. ${ }^{23}$ This has been changed, however, and the duration has been harmonized at the EU level, as well as with U.S. law. ${ }^{24}$ Currently, copyright in the European Union, United Kingdom and the United States subsists in unpublished works for the duration equal to that of copyright in published works - seventy years after the author's death. ${ }^{25}$ Additionally, an important change in the European Union resulted in incentivizing the publication of unpublished works. The Copyright Term Directive, and consequently the U.K. law, ${ }^{26}$ awarded a person an additional twenty-five years of copyright protection for the first lawful publication of a work previously unpublished. ${ }^{27}$

Emails and attachments unpublished elsewhere, therefore, could potentially qualify for the copyright protection as literary works. ${ }^{28}$ However, publishing to a limited number of people is not making the content available to the public, and therefore emails would generally not meet the requirement of publication in the United Kingdom and the United States. ${ }^{29}$ The content could, however, still by copyrighted by meeting the general requirements of originality and fixation, or recording.

1341, 828 U.N.T.S. 221. See also Damien McCallig, Private but Eventually Public: Why Copyright in Unpublished Works Matters in the Digital Age, 10 SCRIPTED 39, 43-44 (2013); Edwards \& Harbinja, supra note 9, at 116.

${ }^{23}$ Copyright protection of unpublished works was perpetual in the United Kingdom until the adoption of The Duration of Copyright and Rights in Performances Regulations 1995, SI 1995/3297, and in the United States until the adoption of the Copyright Act of 1976, 17 U.S.C. $\$ \S 101-810$ (2012), when unpublished works were brought under the federal jurisdiction. See also Elizabeth Townsend Gard, January 1, 2003: The Birth of the Unpublished Public Domain and its International Consequences, 24 CARDOZO ARTS \& ENT. L.J. 687, 697-706 (2006).

${ }^{24}$ See Council Directive 93/98/EEC of 29 October 1993 Harmonizing the Term of Protection of Copyright and Certain Related Rights, 1993 O.J. (L 290) 9; Copyright Act of 1976, 17 U.S.C. $\S 101-810, \S \S 302-303$ (2012).

${ }^{25}$ Directive 2006/116/EC of the European Parliament and of the Council of 12 December 2006 on the Term of Protection of Copyright and Certain Related Rights, art. 1, 2006 O.J. (L 372) 12, 13.

${ }^{26}$ The Copyright and Related Rights Regulations 1996, SI 1996/2967, art. 16 (UK).

${ }^{27}$ Directive 2006/116/EC of the European Parliament and of the Council of 12 December 2006 on the Term of Protection of Copyright and Certain Related Rights, art. 4, 2006 O.J. (L 372) 12, 14.

${ }^{28}$ Copyright, Designs and Patents Act, 1988, c. 1, § 3(1) (U.K.). 17 U.S.C. $\S 101$ (2010).

${ }^{29}$ See Getaped.com, Inc. v. Cangemi, 188 F. Supp. 2d 398 (S.D.N.Y. 2002) (publishing on the website, available to all, constituted publication for the purpose 
Fixation or recording would not create a significant obstacle, as electronic fixation has been recognized as meeting the requirements. ${ }^{30}$ The U.S. law mandates that a work is only fixed "when its embodiment in a copy . . . is sufficiently permanent or stable to permit it to be perceived, reproduced, or otherwise communicated for a period of more than transitory duration." 31 The focus of this definition is on the notion of "a period of more than transitory duration." This has been interpreted by the U.S. courts in a number of cases, including MAI Systems v. Peak Computers, Inc. ${ }^{32}$ There, the court confirmed that reproduction in RAMRandom Access Memory - are fixed copies. This finding is significant as RAM copies are not permanent and are only present while a computer is turned on. ${ }^{33}$

In the United Kingdom, the Copyright, Designs and Patents Act mandates that "Copyright does not subsist in a literary, dramatic or musical work unless and until it is recorded, in writing or otherwise." ${ }^{34}$ Writing is further defined as "any form of notation or code, whether by hand or otherwise and regardless of the method by which, or medium in or on which, it is recorded." ${ }^{35}$ The statutory definition in the United Kingdom appears clearer than the definition in the United States, referring to any medium, therefore including digital recording as well. Accordingly, case law provides that "an artistic work may be fixed in the source code of a computer program." ${ }^{36}$ Consequently, it is clear that the fixation requirement is satisfied in the case of emails. Emails are stored "more than transiently" on the service provider's servers or in the "cloud," and as such are definitely more permanent than RAM.

Originality would arguably create a bigger issue, since many emails contain mere information, such as facts and personal data, and

of 17 U.S.C. $\S 101$ (2010). This interpretation would arguably comply with the Copyright, Designs and Patents Act 1988 c. $48, \S 175$ (U.K.)).

${ }^{30}$ Berne Convention in art. 2, Sept. 28, 1979, 17 U.S.C. $§ 101$ (2010), Copyright, Designs, and Patent Act, 1988, §§ 3(2), 178 (not requiring fixation, but allowing member states to use this requirement in their national law).

${ }^{31} 17$ U.S.C. $\S 101$.

${ }^{32}$ MAI Sys. Corp. v. Peak Computer, Inc., 991 F.2d 511, 518 (9th Cir. 1993).

${ }^{33}$ See also Triad Sys. v. Se. Express Co., 64 F.3d 1330, 1335 (9th Cir. 1995); Stenograph LLC v. Bossard Assocs., Inc., 144 F.3d 96, 102 (D.C. Cir. 1998); Advanced Computer Servs. v. MAI Systems, 845 F. Supp. 356, 363 (E.D. Va. 1994); Intellectual Reserve, Inc. v. Utah Lighthouse Ministry, Inc., 75 F. Supp. 2d 1290, 1294 (D. Utah 1999); Lowry's Reports, Inc. v. Legg Mason, Inc., 271 F. Supp. 2d 737, 745 (D. Md. 2003); Storage Tech. Corp. v. Custom Hardware Eng'g \& Consulting, Inc., 2004 U.S. Dist. LEXIS 12391, 11-12 (D. Mass. 2004).

${ }^{34}$ Copyright, Designs and Patents Act, 1988, c. 48 § 3(2) (U.K.).

${ }^{35}$ Copyright, Designs and Patents Act, 1988, c. 48 \$ 178 (U.K.).

${ }^{36}$ SAS Inst. Inc. v. World Programming Ltd. [2013] R.P.C. 17 II 29. 
probably would not pass the threshold of originality developed by the U.K. and U.S. courts - no matter how low the threshold is. ${ }^{37}$ If we look at the cases involving copyright in letters, it is clear that business correspondence, ${ }^{38}$ a solicitor's letter to his client, ${ }^{39}$ and personal letters ${ }^{40}$ pass this threshold. This can mean that emails that consist of personal or professional correspondence and are of some length-even a few sentences - could satisfy the requirement of originality.

Emails consisting of a single word, phrase, or sentence would have more difficulty, however. Generally, U.K. and EU laws could potentially protect these emails by copyright, but U.S. laws definitely would not. In the U.K., for instance, the book title "Splendid Misery" was denied copyright in Dick v. Yates ${ }^{41}$ as was "the Lawyer's Diary" in Rose

${ }^{37}$ For the US see Burrow-Giles Lithographic Co. v. Sarony 111 U.S. 53, 59-60 (1884); Feist Publ'ns v. Rural Tel. Serv. Co., Inc. 499 U.S. 340, 363 (1991) (“As a constitutional matter, copyright protects only those constituent elements of a work that possess more than a de minimis quantum of creativity. Rural's white pages, limited to basic subscriber information and arranged alphabetically, fall short of the mark."). For the most important UK cases see Walter v. Lane [1900] A.C. 539, 548; Univ. of London Press, Ltd. v. Univ. Tutorial Press, Ltd., [1916] 2 Ch. 601, 608; Interlego AG v. Tyco Indus. Inc. [1989] A.C. 217, 29 (P.C.); Express Newspapers Plc v. News (U.K.) Ltd. [1991] F.S.R. 36, 43 (Ch. D.); Newspaper Licensing Agency, Ltd. v. Marks \& Spencer, Plc, [2001] UKHL 38, [2002] R.P.C. 4 (appeal taken from Eng.). See also, e.g., Daniel J. Gervais, Feist Goes Global: A Comparative Analysis of the Notion of Originality in Copyright Law, 49 J. COPYRIGHT SOC'Y U.S.A. 949, 949-82 (2002); Pamela Samuelson, Originality Standard for Literary Works under U.S. Copyright Law, 42 AM. J. COMP. L. SUPP. 393, 393-418 (1994); Andreas Rahmatian, Originality in UK Copyright Law: The Old "Skill and Labor" Doctrine Under Pressure, 44(1) INST. INTELL. PROP. \& COMPETITION L. 4 (2013); Agustin Waisman, Revisiting Originality, 31(7) EUR. INTELL. PROP. REV. 370 (2009).

${ }^{38}$ Cembrit Blunn Ltd, Dansk Eternit Holding A/S v. Apex Roofing Services LLP, Roy Alexander Leader [2007] EWHC 111, II 238 (Ch.); Tett Bros. Ltd. v. Drake \& Gorham Ltd [1928-1935] MacG. Cop. Cas. 492 (Ch.) (copyright in the following text (omitting "Dear Sir" and "Yours etc.") was held to be infringed: "Further to the writer's conversation with you of to-day's date, we shall be obliged if you will let us have full particulars and characteristics of 'Chrystalite' or 'Barex.' Also we shall be obliged if you will let s have your lower prices for 1, 2, 3,4 and 5 ton lots and your annual contract rates. We have been using a certain type of mineral for some time past and have not found it completely satisfactory, and as we shall be placing an order in the very near future we shall be obliged if you will let us have this information at your earliest convenience").

${ }^{39}$ Musical Fid. Ltd. v. Vickers [2002] EWCA Civ 1989; [2003] FSR 50.

${ }^{40}$ Pope v. Curl (1741) 2 Atk. 342; Lord Perceval v. Phipps 2 V. \& B. 19; Macmillan \& Co. v Dent [1907] 1 Ch. 107.

${ }^{41}$ Dick v. Yates, [1881] 18 Ch. D 76. 
v. Information Services Limited ${ }^{42}$ while in other cases, headings were given the status of literary work and protected by copyright. ${ }^{43}$ The European Court of Justice has subsequently provided some guidance for this issue in the case of Infopaq International A/S v. Danske Dagblades Forening. ${ }^{44}$ The court opined that certain sentences or even parts of them could be copyrightable, depending on the originality of a respective sentence. ${ }^{45}$ This decision has been followed by the English High Court and The Court of Appeal in The Newspaper Licensing Agency Ltd. \& Ors v. Meltwater Holding BV \& Ors. ${ }^{46}$ The High Court applied the Infopaq test and concluded that " $[\mathrm{H}]$ eadlines are capable of being literary works." 47 The judge went even further holding that "it appears that a mere 11 word extract may now be sufficient in quantity provided it includes an expression of the intellectual creation of the author." ${ }^{48}$ The U.S. Copyright Office, on the other hand, outright denies registration of copyright in names, titles, and short phrases. ${ }^{49}$ But even in the United Kingdom, single words are generally refused copyright protection-for example, "Exxon." 50

${ }^{42}$ Rose v. Info. Servs. Ltd., [1987] F.S.R. 254 (Ch.).

${ }^{43}$ Shetland Times Ltd. v. Wills, [1997] F.S.R. 604. (S.C.).

${ }^{44}$ Infopaq Int'l A/S v. Danske Dagblades Forening (Case C-5/08) [2012] Bus. L.R. 102 [2009] E.C.R.

${ }^{45}$ See id. II 47

[T] he possibility may not be ruled out that certain isolated sentences, or even certain parts of sentences in the text in question, may be suitable for conveying to the reader the originality of a publication such as a newspaper article, by communicating to that reader an element which is, in itself, the expression of the intellectual creation of the author of that article. Such sentences or parts of sentences are, therefore, liable to come within the scope of the protection provided for in article 2(a) of that Directive.

${ }^{46}$ The Newspaper Licensing Agency Ltd. \& Ors v. Meltwater Holding BV \& Ors, [2010] EWHC 3099 (Ch.); [2011] EWCA Civ 890.

${ }^{47}$ Id. $\llbracket 71$.

${ }^{48}$ Id. . 77.

${ }^{49}$ See U.S. COPYRIGHT OfFICE, Copyright Protection Not Available for Names, Titles, or Short Phrases, CIRCULAR 34 (2012), http://copyright.gov/circs/circ34.pdf; Becker v. Loew's, Inc., 133 F.2d 889, 893 (7th Cir. 1943); Glaser v. St. Elmo Co., 175 F. 276, 278 (C.C.S.D.N.Y. 1909); Corbett v. Purdy, C.C., 80 F. 901 (C.C.S.D.N.Y. 1897); Osgood v. Allen, 18 F. Cas. 871, 875-76 (C.C.D. Me. 1872) (No. 10,603); Warner Bros. Pictures v. Majestic Pictures Corp., 70 F.2d 310, 311 (2d Cir. 1934); Harper v. Ranous, 67 F. 904, 905 (C.C.S.D.N.Y. 1895); Patten v. Superior Talking Pictures, 8 F. Supp. 196, 197 (S.D.N.Y. 1934).

${ }^{50}$ See Exxon Corp. v. Exxon Ins. Consultants Int'l Ltd., [1982] Ch. 119 (holding the word Exxon does not qualify for copyright protection as an "original literary work."). 
Authors of emails could also retain moral rights, on which the U.K. and U.S. have similar laws. In the United Kingdom, moral rights include: the right to be identified as the author, ${ }^{51}$ the right to object to derogatory treatment of the work, ${ }^{52}$ and the right against false attribution of work. ${ }^{53}$ The first two rights subsist as long as the copyright lasts-70 seventy years post-mortem, and the last one lasts until twenty years after the author's death. ${ }^{54}$ Unless a person waives his moral rights ${ }^{55}$ - the right to be identified as the author and the right to object to derogatory treatment of the work transmit upon death, passing onto the person as directed by will, or a person to whom the copyright passes, or it exercisable by a personal representative. ${ }^{56}$ The right against false attribution is only exercisable by a personal representative, pursuant to the same provision of the CDPA. The U.S. Copyright Act contains a similar provision as to the types of moral rights conferred to the authors. However, these rights expire upon the author's death. ${ }^{57}$

To conclude, despite long emails meeting the requirement of originality and fixation, there would be a regulatory vacuum for a significant number of short emails. Therefore, copyright is insufficient to protect all email communication, necessitating a look at alternative legal mechanisms available to protect this content.

\section{PROPERTY IN EMAILS}

Black-letter law may suggest users may own property in an email's personal data and information. ${ }^{58}$ Together with a copyright regime, this may serve to protect all kinds of email. There may be problems, though, with categorizing email as property.

\section{A. Law on Personal Data as Property}

Personal data consists of a user's name, address, date of birth, genetic data, religious beliefs, photos, among other things. It is

${ }^{51}$ Copyright, Design and Patent Act, 1988, c. 48 § 77 (U.K.).

${ }^{52} I d . \S 80$.

${ }^{53} I d . \S 84$.

${ }^{54} \mathrm{Id}$.

${ }^{55} I d . \S 87$.

${ }^{56} I d . \S 95$.

57 17 U.S.C. $§ 106$ A.

${ }^{58}$ Information encompasses data, ideas, facts, and news, but does not necessarily used in the same manner by the information science literature. Nimmer and Krauthaus distinguish, amongst other criteria they use, differentiation of information by the form of information (summarized data, analyzed data, unorganized and organized raw data). See Raymond T. Nimmer \& Patricia A. Krauthaus, Information as a Commodity: New Imperatives of Commercial Law, 55 LAW \& CONTEMP. PROBS. 103, 110 (Summer 1992). 
traditionally protected by legal regimes based on protection of privacy, undergirded by models based on human rights, torts or contracts. European countries mainly perceive privacy and control over personal data as a human right - establishing the EU-wide data protection regime, which is currently in the process of a comprehensive reform. ${ }^{59}$ The United States, on the other hand, has been using a tort law model. ${ }^{60}$ The tort model, however, has recently penetrated English law in Google Inc v. Vidal-Hall $\&$ Ors,${ }^{61}$ where the Court of Appeal recognized the "tort of misuse of private information." This decision has a potential to revolutionize English law on the protection of personal data.

Although protected under a tort-privacy right, personal data have not traditionally been protected under a property right. The advantage of a property regime is that, unlike a tort-privacy regime, there is no need for individuals to demonstrate harm in order to be able to protect their property - and this holds for both U.S. and U.K. legal regimes. ${ }^{62}$ But for the property rights model to adhere, personal data must compose an asset or commodity. ${ }^{63}$ This has been the subject of extensive debate. Nevertheless, proponents argue that a property regime would enable individuals to better control the use of personal data and to better share in the profits resulting from such use, and would force companies to internalize these new costs when deciding to collect or use others' personal data. ${ }^{64}$ In addition, since property rights are rights in rem and can be enforced against anyone, proponents argue that individuals could protect

\footnotetext{
${ }^{59}$ The Charter of Fundamental Rights of the European Union, art. 8, Dec. 7, 2000. See, e.g., Corien Prins, Privacy and Property: European Perspectives and the Commodification of our Identity, in THE FUTURE OF THE PUBLIC DOMAIN 223, 223-57 (Lucie Guibault \& Bernt Hugenholtz eds., 2006).

${ }^{60}$ Restatement (Second) of Torts $\S \S 652 \mathrm{~A}-652 \mathrm{E}$ (1977); Andrew J. McClurg, $A$ Thousand Words are Worth a Picture: A Privacy Tort Response to Consumer Data Profiling, 98 Nw. U. L. REV. 63 (2003).

${ }^{61}$ Google v. Vidal-Hall, 2015 WL 1310650 (2015).

${ }^{62}$ See id. at 247.

${ }^{63}$ See e e.g., World ECON. Forum, Personal Data: The EMERgenCE OF A NeW ASSET ClASS 5, 7, http://www3.weforum.org/docs/WEF_ITTC_Personal DataNewAsset_Report_2011.pdf.

${ }^{64}$ Pamela Samuelson, Privacy As Intellectual Property?, 52 STAN. L. REV. 1125, 1128 (1999).
} 
their data not only against data controllers, ${ }^{65}$ but against third parties as well. ${ }^{66}$

Most of these "propertization" arguments originate in the United States, although there are some examples in the European context. For example, Prins characterizes the EU regime as utilitarian - as it aims to promote the free flow of personal data-and therefore more receptive to a property regime than that of the United States. ${ }^{67}$ Similarly, Purtova argues it would enable better control of personal data within the European Union, despite differences in property concepts between common and civil law countries. ${ }^{68}$ She argues primarily for introducing the protective features of property with respect to third parties, rather than its alienability feature. ${ }^{69}$ In an earlier work, this author has argued that due to the introduction of the right to be forgotten and data portability rights, the proposed data protection regulation is moving towards the propertization of personal data. $^{70}$

There are, nevertheless, notable disadvantages of the property model. For example, this model may produce monopolization of

65 "Data controllers" is the EU data protection concept, meaning "the natural or legal person, public authority, agency or any other body which alone or jointly with others determines the purposes and means of the processing of personal data; where the purposes and means of processing are determined by national or Community laws or regulations, the controller or the specific criteria for his nomination may be designated by national or Community law." See The Data Protection Direction 95/46/EC, art. 2 d, 1995 (E.U.) (directive on the protection of individuals with regard to the processing of personal data and on the free movement of such data).

${ }^{66}$ See Bert-Jaap Koops, Forgetting Footprints, Shunning Shadows: A Critical Analysis of the 'Right to Be Forgotten' in Big Data Practice, 8 SCRIPTED 256, 256-58 (2011). Or for the U.S. perspective, see Chris CONLEY, THE RIGHT TO DELETE

https://www.aaai.org/ocs/index.php/SSS/SSS10/paper/view/1158.

${ }^{67}$ Prins, supra note 59, at 245.

${ }^{68}$ See Nadezhda Purtova, Property in Personal Data: Second Life of an Old Idea in the Age of Cloud Computing, Chain Informatisation, and Ambient Intelligence, in Computers, PRIVACY AND DATA PROTECTION: AN ElEMENT OF ChOICE 61 (Serge Gutwirth et al. eds., 2011) ("Property, with some limitations resolved by regulation, due to its erga omnes effect and fragmentation of property rights, has the potential to reflect and control this complexity of relationships. This may be considered an instance of property exercising its protective rather than market function; it aims at making sure that even after transfer of a fraction of rights, a data subject always retains basic control over his personal information."). ${ }^{69} \mathrm{Id}$.

${ }^{70}$ Edina Harbinja, Does the EU Data Protection Regime Protect Post-Mortem Privacy and What Could Be The Potential Alternatives?, 10 SCRIPTED J. L. Tech. \& Soc'y 19, 19 (2013). 
information and prevent freedom of speech. ${ }^{71}$ Additionally, the property model may encourage transactions in personal data, which arguably should be discouraged. The principle of alienability would allow the purchaser to then sell the data again, attenuating control of the original owner. ${ }^{72}$ This argument, however, presumes the full alienability of property. This does not have to be the case. ${ }^{73}$ Personal data could be subject to "hybrid alienability," 74 or a model resembling the limited rights granted under copyright law, rather than a "traditional" property right that would completely divorce the original owner from all control. ${ }^{75}$

In summary, personal data has never been legally protected as property. Instead, protection of personal data has been provided through data protection legislation, as torts or by breach of confidence. Propertization arguments remained at the theoretical level, without an influence to the legislation or case law. ${ }^{76}$ It puts forth workable ideas, such as "hybrid alienability," but evidence also suggests many problems in conceiving personal data as property. These problems notably include a conflict with the human right of privacy. Propertization of personal data, therefore, remains a theoretical construct, and a rather unsuccessful one so far.

\section{B. Law on Information as Property}

Information is not generally regarded as property in black-letter law, and especially within the English common law. For instance, in

${ }^{71}$ See infra note 151 and accompanying text.

72 Samuelson, supra note 64, at 1136; Jessica Litman, Information Privacy/Information Property, 52 STAN. L. REV. 1283, 1304 (2000); see also Julie E. Cohen, Examined Lives: Informational Privacy and the Subject as Object, 52 STAN. L. REV. 1373,1391 (2000).

${ }^{73}$ See, e.g., Jane B. Baron, Property as Control: The Case of Information, 18 Mich. Telecomm. \& TeCH. L. ReV. 367, 382-83 (2012); Paul M. Schwartz, Property, Privacy, and Personal Data, 117 HARV. L. REV. 2055, 2093 (2004); Susan Rose-Ackerman, Inalienability and the Theory of Property Rights, 85 COLUM. L. REV. 931 (1985) (arguing that "alienability is not a binary switch to be turned on or off, but rather a dimension of property ownership that can be adjusted in many different ways"); Lee Ann Fennell, Adjusting Alienability, 122 HARV. L. REV. 1403, 1408 (2009).

${ }^{74}$ Schwartz, supra note 73, at 2094-98 (discussing model of property rights in personal data, which would "permit the transfer for an initial category of use in personal data, but only if the customer is granted an opportunity to block further transfer or use by unaffiliated entities").

${ }^{75}$ See Cohen, supra note 72, at 1428-29.

${ }^{76}$ See id. at 21 ('Post-mortem privacy (deceased persons' privacy), has been, so far, a phenomenon of interest predominantly for sociologists, psychologists, anthropologists and other humanities and social sciences scholars. This issues, nevertheless, deserves the attention of legal scholarship ...."). 
Boardman $v$ Phipps, ${ }^{77}$ the court maintained that information is not property in any normal sense, but equity will restrain its transmission to another if in breach of some confidential relationships. ${ }^{78}$ There are some earlier authorities in English common law conferring proprietary character to certain kinds of information. These include Jeffrey $v$. Rolls Royce Ltd ${ }^{79}$ where Lord Redcliffe was treated as an asset distinct from the physical records it was contained ${ }^{80}$; Herbert Morris Ltd v. Saxelby ${ }^{81}$ where trade secrets were considered "his master's property"82; and Dean $v$. MacDowell, ${ }^{83}$ where information constituted property of the partnership. ${ }^{84}$ An infamous case where an English court found property in information is Exchange Telegraph Co. v. Gregory \& Co. ${ }^{85}$ There, the Court of Appeal upheld an injunction to restrain the defendant broker from publishing information-the quotations in stocks and shares from the Stock Exchange - on the grounds that the information was the plaintiff's property ${ }^{86}$ However, this stance has not been supported in most of the subsequent case law. ${ }^{87}$ Other rules of law, like contract, tort and breach of confidence, are desired instead. ${ }^{88}$

In the United States, authorities asserting information as property vary significantly among the individual states, but courts are generally more willing to recognize certain kinds of information as property. In U.S. International News Service. v. Associated Press ${ }^{89}$ the Supreme Court held that fresh news could be regarded as quasi-property, provided that misappropriation by a competitor constitutes unfair competition..$^{90}$ Both

77 [1967] 2 AC 46 (HL) (appeal taken from England).

${ }^{78} \mathrm{Id}$. at 128.

79 [1962] 1 AER 801 (HL) (appeal taken from England).

${ }^{80} \mathrm{Id}$. at 805.

${ }^{81}$ [1916] 1 AC 688 (HL) (appeal taken from England).

${ }^{82} \mathrm{Id}$. at 714 .

83 (1878) 8 Ch D 345 (Eng.).

${ }^{84} \mathrm{Id}$. at 354 .

85 [1896] 1 QB 147.

${ }^{86}$ See id. at 152-53 (Lord Esher M.R.) ("This information . . . is something which can be sold. It is property, and being sold to the plaintiffs it was their property. The defendant has, with intention, invaded their right of property in it, and he has done so surreptitiously and meanly.").

87 Paul Kohler \& Norman Palmer, Information as Property, in INTERESTS IN Goods 7 (Norman Palmer \& Ewan McKendrick eds., 2d ed. 1993).

${ }^{88} \mathrm{Id}$. at $4-5$.

89248 US 215 (1918).

${ }^{90}$ See id. at 236 ("Regarding the news, therefore, as but the material out of which both parties are seeking to make profits at the same time and in the same field, we hardly can fail to recognize that for this purpose, and as between them, it must be regarded as quasi property, irrespective of the rights of either as against the public."). There, the Court used a classical Lockean justification for establishing 
state and federal courts have adopted the doctrine as a general rule of unfair competition, thus granting protection to objects outside the reach of intellectual property protection. But it has been widely criticized for its lack of analysis and superficiality..$^{91}$ There is a fear this doctrine protects objects that intellectual property will not, ${ }^{92}$ potentially restricting access to the public domain and upsetting the balance intellectual property law attempts to achieve. ${ }^{93}$ The doctrine has been a subject of wide controversy in American academic writing. ${ }^{94}$ Nonetheless, lower courts have followed the rule of misappropriation set forth in International News Service. ${ }^{95}$

In contrast to the misappropriation theory under U.S. law, England established the doctrine of "breach of confidence," aimed at providing protection for valuable information. ${ }^{96}$ Breach of confidence is an equitable doctrine that can be described as similar to the American "trade secret law" doctrine. ${ }^{97}$ In this way, a recent Court of Appeal case decided that confidential information should be regarded as a type of intellectual

quasi-property in news, invoking the pains and labor that were taken advantage of by the plaintiff's competitor. The case was a base for developing the doctrine of misappropriation in the United States.

${ }^{91}$ Stanley M. Besen \& Leo J. Raskind, An Introduction to the Law and Economics of Intellectual Property, 5 J. ECON. PERSP. 3, 25 (1991).

${ }^{92}$ Such as fact, for instance. See Int'l News Serv. v. Assoc. Press, 248 U.S. 215, 250 (1918) (Brandeis, J., dissenting) ("The general rule of law is, that the noblest of human productions - knowledge, truths ascertained, conceptions, and ideasbecome, after voluntary communications to others, free as the air to common use.").

${ }^{93}$ See infra notes 152 to 173 and accompanying text.

${ }^{94}$ See, e.g., Douglas G. Baird, Common Law Intellectual Property and the Legacy of International News Service v. Associated Press, 50 U. CHI. L. REV. 411, 411 (1983); Edmund J. Sease, Misappropriation is Seventy-Five Years Old; Should We Bury It or Revive It?, 70 N.D. L. REV. 781, 781 (1994); Raymond A. Be, Dead or Alive?: The Misappropriation Doctrine Resurrected in Texas, 33 Hous. L. REV. 447, 449 (1996).

${ }^{95}$ Rex Y. Fujichaku, The Misappropriation Doctrine in Cyberspace: Protecting the Commercial Value of "Hot News" Information, 20 U. HAW. L. REV. 421, 447 (1998). Most of the cases where courts did recognize a misappropriation action involved either appropriation of breaking news or sports performances, likely because that information was a source of revenue for media companies. See, e.g., Assoc. Press v. KVOS, Inc., 80 F.2d 575 (9th Cir. 1935), rev'd on other grounds, 299 U.S. 269 (1936); Pottstown Daily News Publ'g Co. v. Pottstown Broad. Co., 192 A.2d 657 (Pa. 1963); 202 Pittsburgh Athletic Co. v. KQV Broad. Co., 24 F. Supp. 490 (W.D. Pa. 1938); Twentieth Century Sporting Club v. Transradio Press Serv., 300 N.Y.S. 159 (N.Y. Sup. Ct. 1937).

${ }^{96}$ Charlotte WaEldE ET Al, CONTEMPORARy INTELleCtUAl Property: LAW AND POLICY 774 (3rd ed. 2013).

${ }^{97} \mathrm{Id}$. at $775-76$. 
property. ${ }^{98}$ This, however, is an exceptional decision, and it does not follow the principles established in the bulk of English case law. Indeed, English courts seem to agree that information cannot be considered property, ${ }^{99}$ and arguably, that protection instead lies in tort law. For example, in $O B G v$ Allan, the court stated that "[i]nformation, even if it is confidential, cannot properly be regarded as a form of property." 100 Similarly, in Moorgate Tobacco v Philip Morris, the court, writing about breach of confidence, declared that confidence's "rational basis does not lie in proprietary right." Rather, "it lies in the notion of an obligation of conscience arising from the circumstances in or through which the information was communicated or obtained."101

As stated before, the doctrine of trade secrets is the American counterpart to breach of confidence in England. The Uniform Trade Secrets Act broadly defines trade secrets as any information that is secret, derives economic value from secrecy, and is the subject of reasonable measures to maintain its secrecy. ${ }^{102}$ Trade secrets can protect many types of information, ${ }^{103}$ and arguably evolved from a property regime in the nineteenth century to a combination of contracts, torts and property, and eventually to the unfair competition approach adopted by the Restatement of Torts in 1939. ${ }^{104}$ In England that shift never happened, and trade secrets remain protected by the breach of confidence doctrine.

${ }^{98}$ Coogan v. News Group Newspapers Ltd. [2012] EWCA (Civ) 48 (Eng.).

99 See, e.g., M. Conaglen, Thinking about Proprietary Remedies for Breach of Confidence, 1 INTELL. PROP. Q. 82, 84 (2008) ("[T] he prevailing modern view is that the foundation of the doctrine of confidence does not rest in the protection of property.”); SNELL'S EQUITY, 16-07-16-11 (J.A. McGhee ed., 2004); W. Cornish \& D. Llewelyn, Intellectual Property: Patents, Copyright, Trade MARKS AND ALLIED RIGHTS, 8-50-54 (2007).

100 OBG Ltd. v. Allan [2007] UKHL 21 at 275 (Eng.).

101 Moorgate Tobacco Co. Ltd. v. Philip Morris Ltd. (No.2) [1984] 156 C.L.R. 414, 438 (Eng.). See also Boardman v. Phipps [1967] 2 A.C. 46, 89-90, 102, 12728 (Eng.); Breen v. Williams [1996] 186 C.L.R. 71, 81, 91, 111-12, 129; Cadbury Schweppes Inc. v. FBI Foods Ltd. [1999] 167 D.L.R. (4th) 577 [48]; Douglas v. Hello! Ltd. (No.3) [2005] EWCA (Civ) 595 (Eng.); [2006] Q.B. 125 [119, 126].

102 Uniform Trade Secrets Act, 14 U.L.A. 529 § 1(4) (2005). However, U.S. courts tend to instead use the negative definition, defining trade secrets "by what [they are] not." D. S. Almeling, Seven Reasons Why Trade Secrets Are Increasingly Important, 27 BERKELEY TECH. L.J. 1091, 1107 (2012).

${ }^{103}$ See id. (explaining trade secrets cover items such as chemical formulas, source code, methods, prototypes, pre-release pricing, financials, budgets, contract terms, business plans, market analyses, salaries, information about suppliers and customers, experiments, positive and negative experimental results, engineering specifications, laboratory notebooks, and recipes).

${ }^{104}$ Restatement of Torts $\S 757$ (1939). 
Trade secret doctrine's proprietary roots can be seen in certain American decisions that describe trade secrets as primarily property. ${ }^{105}$ One of the earliest cases deeming trade secrets to be property is Peabody v. Norfolk. ${ }^{106}$ There, the Massachusetts Supreme Judicial Court defined a principle applicable to property law in general. ${ }^{107}$ Regarding trade secrets, the court said that the inventor or discoverer of secret information does not have exclusive rights against the public or the good faith acquirer, "but he has a property in it, which a court of chancery will protect against one who in violation of contract and breach of confidence undertakes to apply it to his own use, or to disclose it to third persons." 108 Later, the courts continued to connect trade secrets to property. In 1984, The Supreme Court held that trade secrets are property for purposes of the Fifth Amendment's Takings Clause. ${ }^{109}$ Additionally, since trade secrets are intangible, the Court stated that the existence of a property right depends on the extent to which the trade secret is protected from disclosure. ${ }^{110}$

Despite its proprietary origins and select decisions throughout the years, U.S. courts have never decided with certainty whether confidential information or trade secrets are property. In addition to intellectual property, American academia has counted it as part of torts, or something that belongs in the criminal law domain. ${ }^{111}$ Commentators assert trade

105 See, e.g., Restatement (Third) of Unfair Competition $\S 39 \mathrm{cmt} . \mathrm{b}$ (1993) (describing early trade secret theory as based on property rights); Carpenter v. United States, 484 U.S. 19, 26 (1987) ("Confidential business information has long been recognized as property."); Electro-Craft Corp. v. Controlled Motion, Inc., 332 N.W. 2d 890, 897 (Minn. 1983) ("In defining the existence of a trade secret as the threshold issue, we first focus upon the "property rights" in the trade secret rather than on the existence of a confidential relationship."); IMED Corp. v. Sys. Eng'g Assocs. Corp., 602 So.2d (Ala. 1992) ("Our conclusion in this regard is consistent with the purpose of the act - to protect individual property rights in trade secrets ....").

10698 Mass. 452, 457-58 (1868).

${ }^{107}$ See id. at 457 ("If a man establishes a business and makes it valuable by his skill and attention, the good will of that business is recognized by the law as property.").

${ }^{108} I d$. at 458.

${ }^{109}$ Ruckelshaus v. Monsanto Co., 467 U.S. 986, 1002-03 (1984) (citing Locke's Second Treatise and other sources to support the finding that trade secrets can be property). See also J. W. Hill, Trade Secrets, Unjust Enrichment, and the Classification of Obligations, 4 VA. J. L. \& TECH. 2 (1999).

${ }^{110}$ Ruckelshaus, 467 U.S. at 1002; see also Kewanee Oil Co. v. Bicron Corp., 416 U.S. 470, 474-76 (1974) (noting the importance of secrecy to the value of trade secrets).

${ }^{111}$ See, e.g., Christopher Rebel J. Pace, The Case for a Federal Trade Secrets Act, 8 Harv. J. L. \& TECH. 427, 435-42 (1995); David D. Friedman et al., Some Economics of Trade Secret Law, 5 J. ECON. PERSP. 61 (1991); Gale R. Peterson, 
secret law involves elements of similar areas: property, contract, tort, fiduciary duty, and criminal law. ${ }^{12}$ American trade secret law may after all be a fusion of tort and unjust enrichment law. ${ }^{113}$ Still some believe this inquiry is not essential and that what matters is that the information is actually protected. ${ }^{114}$ Nevertheless, it is worth noting that many authors still argue that trade secrets are intellectual property rights. ${ }^{115}$

All things considered, U.S. courts and legislators have been more willing to recognize information as property. But the property paradigm cannot be used for all kinds of information and for all cases because it relates to commercially valuable information mainly. Although the property paradigm may succeed in the future, ${ }^{116}$ only tangible objects are

Trade Secrets in an Information Age, 32 Hous. L. REv. 385 (1995); E. W. Kitch, The Law and Economics of Rights in Valuable Information, 9 J. LEGAL STUD. 683 (1980); W. B. Barton, A Study in the Law of Trade Secrets, 13 U. CIN. L. REv. 507, 558 (1939); C. T. Graves, Trade Secrets as Property: Theory and Consequences, 15 J. InTEll. Prop. L. 39 (2007); M. Risch, Why Do We Have Trade Secrets?, 11 MARQ. INTELL. PROP. REV. 1 (2007); V. Chiappetta, Myth, Chameleon, or Intellectual Property Olympian?: A Normative Framework Supporting Trade Secret Law, 8 GEO. MASON L. REV. 69 (1999); Hill, supra note 109; C. Montville, Reforming the Law of Proprietary Information, 56 DUKE L.J. 1159 (2007); M. P. Simpson, Trade Secrets, Property Rights, and Protectionism - an Age-Old Tale, 70 BROOK. L. REV. 1121 (2005); J. Chally, The Law of Trade Secrets: Toward a More Efficient Approach, 57 VAND. L. REV. 1269 (2004).

${ }^{112}$ See Hill, supra note 109.

${ }^{113}$ See id. The legislation of trade secrets has been quite a recent phenomenon in the US. Before 1980, there was no legislation on this matter. The initial efforts to codify and harmonize trade secrets law was that of the Uniform Law Commission, which in 1979 adopted the uniform Trade Secrets Act. Following this important event, forty-seven states in total enacted civil statutes and over a half of these states also have specific criminal provision on trade secrets. In addition, in 1996, Congress passed a federal statute criminalizing trade secret misappropriation, Economic Espionage Act 18 U.S.C. 55 1831-39. See Uniform Trade Secrets Act, 14 U.L.A. § 529 (2005); D. S. Almeling et al., A Statisical Analysis of Trade Secret Litigation in State Courts, 46 GoNZ. L. REV. 57, 67-68 (2011).

114 See Amedee E. Turner, The LaW of Trade SeCrets 12 (1962); E.I. du Pont de Nemours Co. v. Masland, 244 U.S. 100, 102 (1917); see also Nature of Trade Secrets and Their Protection, 42 HARV. L. REV. 254 (1928) (noting that property theories of trade secret protection have limitations and that, in the end, it may not matter whether courts regard trade secrets as property, provided they protect them).

115 See Mark A. Lemley \& Phillip J. Weiser, Should Property or Liability Rules Govern Information?, 85 TEX. L. REV. 783, 789 (2007).

${ }^{116}$ Kohler \& Palmer, supra note 87, at 206 (noting that the information might be deemed to be property in the future, and it would provide the courts with an additional instrument). 
currently protected with certainty, ${ }^{117}$ leaving the protection of intangible information uncertain. ${ }^{118}$

\section{The Fairstar Case}

The question of whether new, intangible information such as emails should be regarded as property arose in the recent English case, Fairstar Heavy Transport N.V. v Adkins. ${ }^{119}$ This section will examine the scenarios identified by the court in more detail. Justice Edwards-Stuart's analysis of property in emails illustrates five different scenarios: 1) the title remains with the creator; 2) the title passes to the recipient (analogous to a letter); 3) the recipient had a license to use the content of the email, 4) the sender has a license to retain the content and use it, and 5) the title is shared between the sender and the recipient, as well as any subsequent recipient. $^{120}$

In each of these scenarios, Judge Edwards-Stuart focused on the unwanted consequences that would follow if the information in emails were to be recognized as property. Under the first scenario, (the creator of the email content retains property in it) he noted that the in rem nature of property would entitle the sender to request deletion of the email. The judge noted that this "would be very strange - and far reaching."121 Under the second scenario (the recipient has the property right), he pointed out, similarly, that the recipient would instead be entitled to request deletion. In addition to that "strange outcome", he noted that further complications would arise if the email were forwarded to many recipients, who in turn might forward it to even more recipients. There, "the question of who had the title in its contents at any one time would become hopelessly confused." "122 Under the third and fourth scenarios (recipient and sender, respectively, have license to use the content), Justice Edwards-Stuart noted that a property concept and a confidentiality concept would be redundant. Namely, if information was confidential then property offers no extra protections, and if the information was not confidential then there would be almost no need to use property's protections. He concluded that a change to a property regime was not necessary in light of these options, stating that "there is no compelling need or logic for adopting either of

117 See Thurston v. Charles [1905] 21 T.L.R. 659; British Steel Corp. v. Granada Television Ltd. [1981] A.C. 1096, 1105 per Megarry V.C. (Eng.); Kohler \& Palmer, supra note 87 , at 188.

118 See Kohler \& Palmer, supra note 87, at 188.

119 Fairstar Heavy Transport N.V. v. Adkins, [2012] EWHC (TCC) 2952, [64]

(Eng.).

${ }^{120} \mathrm{Id}$. at 61.

${ }^{121}$ Fairstar Heavy Transport N.V. v. Adkins, [2012] EWHC (TCC) 2952, [64]

(Eng.).

122 Id. II 66. 
options (3) or (4) and so in relation to these options I would reject a plea that the law is out of line with the state of technology in the $21^{\text {st }}$ century." 123

Under the fifth scenario (shared proprietary interests in email contents), Justice Edwards-Stuart discussed several possible consequences of the loss of information in emails due to technology issues. He argued that, in such cases, the affected party could not gain access to the servers of the parties with whom he shared property in emails. He concluded that "the ramifications would be considerable and, I would have thought, by no means beneficial." 124 Accordingly, he concluded that emails are not to be considered property. ${ }^{125}$

Subsequently, the Court of Appeal recognized the same conceptual difficulties. ${ }^{126}$ However, the Court further asserted that this does not mean that there can never be property in any kind of information, as the inquiry depends on the quality of the information in question. ${ }^{127}$ This would mean that information such as "know-how" might be susceptible to property, as opposed to personal data. ${ }^{128}$ Accordingly, the Court wisely avoided this discussion and decided that the real issue in the case was that of agency, stating an agent must allow the principal access to information sent on its behalf. ${ }^{129}$ In another, even more recent case, the Court of Appeal confirmed this long-standing position and, in relation to the customer data contained within a database, maintained that information is not regarded

${ }^{123}$ Id. \I 67.

${ }^{124} I d$. II 68.

${ }^{125}$ Id. II 69.

126 "The claim to property in intangible information presents obvious definitional difficulties, having regard to the criteria of certainty, exclusivity, control and assignability that normally characterize property rights and distinguish them from personal rights." Fairstar Heavy Transport N.V. v. Adkins [2013] EWCA (Civ) 886, [47].

${ }^{127} I d$. II 48.

${ }^{128} \mathrm{Id}$.

129 "In my view, it is unfortunate that the agreed wording of the preliminary issue introduced an unnecessary complication into the dispute. The reference to a 'proprietary right' was a distraction from the centrality of the agency relationship and its legal incidents. No competing claims of third parties are involved. Fairstar's claim is against Mr Adkins. The assertion of a right to inspect and copy the content of the emails on his computer relating to its business affairs arises from the legal incidents of an agency relationship that survive its termination. That question can be decided, as between those parties, without a jurisprudential debate about the legal characteristics of 'property,' or whether the content of the emails was 'information' in which property existed in this case or could exist at all." Id. II 46. 
as property in English law. ${ }^{130}$ Conversely, the medium carrying information is an object of property. ${ }^{131}$

In conclusion, it can be generally argues that the U.K. courts do not consider information property, whereas U.S. law has done so more readily.

\section{THEORIES OF PROPERTY APPLIED TO INFORMATION}

In this section, different theories are put forth to determine whether one may undergird a property conception of information in emails. None, however, are sufficient to accomplish this.

\section{A. Property as a "Bundle of Sticks"}

The particular framework used to examine these stances is the most widely accepted conception of property in common law systems: the "bundle of sticks" theory. In the information context, this theory encompasses the following 'sticks': the control of copying, access, modification, use, and disclosure of data and information. ${ }^{132}$

Providing for all of the sticks in the bundle of information context is usually a complex task, if possible at all, due to the characteristics that differentiate information from traditional, tangible property. For example, information is non-rivalrous, ${ }^{133}$ as possession can be concurrent and

130 "An electronic database consists of structured information. Although information may give rise to intellectual property rights, such as database right and copyright, the law has been reluctant to treat information itself as property. When information is created and recorded there are sharp distinctions between the information itself, the physical medium on which the information is recorded and the rights to which the information gives rise. Whilst the physical medium and the rights are treated as property, the information itself has never been. As to this, see most recently per Lord Walker in OBG Ltd $v$ Allan [2007] UKHL 21, [2008] 1 A.C. 1 at [275], where he is dealing with the appeal in Douglas v Hello, and the discussion of this topic in Green \& Randall, The Tort of Conversion at pages 141144." Your Response Ltd. v. Datateam Bus. Media Ltd. [2014] EWCA (Civ) 281 [42] (Lord Justice Floyd) (appeal taken from Brighton Cty. Ct.) (Eng.).

131 "When information is created and recorded there are sharp distinctions between the information itself, the physical medium on which the information is recorded and the rights to which the information gives rise. Whilst the physical medium and the rights are treated as property, the information itself has never been." Id.

132 See Nimmer \& Krauthaus, supra note 58, at 113.

133 See James Boyle, The Second Enclosure Movement and the Construction of the Public Domain, 66 LAW \& CONTEMP. PROBS. 33, 41 (2003); R. Grant Hammond, Quantum Physics, Econometric Models and Property Rights to Information, 27 MCGILL L.J. 47, 54 (1981); Mark A. Lemley, Property, Intellectual Property, and Free Riding, 83 TEX. L. REV. 1031, 1059-60 (2005). 
cannot be transferred as in the case of tangible property; ${ }^{134}$ information is often non-separable, acting as a part of an individual right holder; ${ }^{135}$ copying information is easy and not very costly, ${ }^{136}$ information is often time-limited, erasable, and more fluid; ${ }^{137}$ information is not easily excludable, requiring legal measures to mandate its excludability; ${ }^{138}$ information generally does not depreciate with use and sometimes even gains additional value with use, ${ }^{139}$ and information is not scarce. ${ }^{140}$

These differences make it difficult to apply the traditional property "sticks" (such as use, control, exclusion, possession, destruction) to information. On this basis, courts frequently deny information a status of property. Nevertheless, major western theories can still be evaluated in their ability to establish property rights in information. ${ }^{141}$

\section{B. Labor Theory}

This section evaluates labor theory as a justification of the propertization of information, as it is widely used. ${ }^{142}$ According to Locke,

${ }^{134}$ Nimmer \& Krauthaus, supra note 58, at 105.

135 "Separability" or "thinghood", means that the things, in order to be property, must not be conceived as "an aspect of ourselves or our ongoing personality-rich relationships to others.” J.E. PENNER, THE IDEA OF PROPERTY IN LAW 126 (1997). 136 See Hammond, supra note 133, at 54. Usually, with the exception of highly confidential and protected information, where it could be considerably harder and costlier.

${ }^{137}$ Persistence is another quality of property objects, both tangible and intangible. It does not mean permanence; it only implies a certain degree of stability. See Theodore J. Westbrook, Owned: Finding a Place for Virtual World Property Rights, 2006 MicH. ST. L. REV. 779, 782-83 (2006).

${ }^{138}$ For more on excludability, see Boyle, supra note 133, at 42. For Hammond, public goods are separated from private goods by a principle of exclusion and for information to have this feature, a considerable cost would need to occur. Hammond, supra note 133, at 54.

139 See Boyle, supra note 133, at 44.

${ }^{140}$ See Hammond, supra note 133, at 53.

141 This discussion will borrow from the normative justifications for the recognition of intellectual property. The reason for this is that the same major property theories have been used to justify both intellectual property rights and propertization. In addition to the same rationale, intellectual property variants of these theories are even more suitable in the information context, given that intellectual property resources share many of the same features as information, as they too are intangible, non-rivalrous, and non-permanent.

142 Justin Hughes, The Philosophy of Intellectual Property, 77 Geo. L.J. 287 (1989); William Fisher, Theories of Intellectual Property, in NEW ESSAYS IN THE LEGAL AND POLITICAL THEORY OF PROPERTY 168, 296-329 (Stephen R. Munzer ed., 2007); Seana V. Shiffrin, Lockean Arguments for Private Intellectual Property, in NEW ESSAYS IN THE LEGAL AND POLITICAL THEORY OF PROPERTY 138, 138-39 (Stephen R. Munzer ed., 2007). 
a creator owns his person and his labor. Because inventions and intellectual creations are products of labor, the creator owns them according to this theory. But when applying this to information generally, one encounters problems.

First, information such as facts, news, or things not qualifying as intellectual property may not entail labor. With information, there is no laboring on independent physical materials. ${ }^{143}$ Other problems may arise with Locke's proviso concerning spoilage, as intellectual property and information are not subject to spoilage in the material sense. Although spoilage may occur if the creator fails to use all of the owned information in productive ways, ${ }^{144}$ only the complete non-usage of works would result in spoilage, which would be rare. ${ }^{145}$

Though this Lockean proviso may not exactly apply, concerns over the failure to properly use information are warranted. Some types of information (for example, trade secrets or personal data) may lose their usefulness and function if not used in the right time and exploited properly, a scenario that relates back to the tragedy of the commons arguments. ${ }^{146}$ However, the "commons" analogy and its prescriptions may not be equipped to address these concerns, as it does with tangible property, for it is very difficult to define the commons abstractly in the case of information. We could borrow from intellectual property theory and consider the commons equivalent to the IP public domain. However, this approach would encounter similar difficulties that the public domain faces. The main objection is that the Lockean commons referred to appropriation

143 "The Lockean labor theory applies more easily because the common of ideas seems inexhaustible." Hughes, supra note 142, at 51. For a more detailed discussion, see Shiffrin, supra note 142, at 140, 141, or GREGORY S. ALEXANDER \& EdUARDO. M. PEÑAlVER, AN INTRODUCTION TO PROPERTY THEORY 191, 192 (2012).

${ }^{144}$ Benjamin G. Damstedt, Limiting Locke: A Natural Law Justification for the Fair Use Doctrine, 112 YALE L.J. 1179, 1182, 1183 (2003).

${ }^{145}$ ROBERT P. MERGES, JUSTIFYING INTELLECTUAL PROPERTY 58 (2011).

${ }^{146}$ The "tragedy of commons" is a well-known and widely built upon concept in the US, created by Garrett Hardin. A tragedy of the commons is a situation appearing when too many owners have a privilege to use a resource and no one has a right to exclude another. This leads to overuse and depletion of the resource. Garrett Hardin, The Tragedy of the Commons, 162 SCIENCE 1243, 1248 (1968). Demsetz also discusses intellectual property. Harold Demsetz, Toward a Theory of Property Rights, 57 Am. ECON. Rev. 347, 359 (1967). See also F. Scott Kieff, Property Rights and Property Rules for Commercializing Inventions, 85 MINN. L. REV. 697 (2001); Edmund Kitch, The Law and Economics of Rights in Valuable Information, 9 J. LEGAL STUD. 683, 683-723 (1980); William M. Landes \& Richard A. Posner, An Economic Analysis of Copyright Law, 18 J. Legal Stud. 325,353 (1989). 
in an earlier stage of societal development, and to tangible assets only, thus being inapplicable to the public domain and, consequently, to the case of information commons. ${ }^{147}$

Locke's proviso concerning limitation on appropriation, however, may nevertheless apply. ${ }^{148}$ Although, theoretically, the "enough and as good" proviso is likely to be satisfied due to information not being scarce, thus rendering the proviso unnecessary, scarcity may still occur with negative consequences if appropriation prevents the dissemination of important information. ${ }^{149}$ For instance, some information could be necessary for self-preservation and subsistence, as required by Locke, making its appropriation harmful to the welfare of others. As a result, there would not be "enough and as good" left for others in the commons if the access were to be limited by property rights. ${ }^{150}$ This is especially true if propertization would, as suggested by many prominent commentators, jeopardize free speech, expression, sharing of knowledge and keeping archives and accurate history records. ${ }^{151}$

Generally, labor theory could be employed to justify property in certain kinds of information, where labor that could qualify as adequate for the purpose of labor theory (e.g., trade secrets) is present. However, general application to all kinds of information is unsuitable. Finally, the commons is even more problematic in the case of personal data, as such data is, by definition, tied to an individual and does not belong to everyone. Accordingly, labor theory is even less applicable to personal data.

\section{Utilitarian Theory}

This section will first explain the utilitarian theories used to justify intellectual property and will then draw parallels with applying the theory to propertizing information. Inspired by Bentham, utilitarians and the neoclassical law and economics school argue that the main purpose of awarding intellectual property protection is incentivizing innovation. ${ }^{152} \mathrm{In}$

147 See Shiffrin, supra note 142, at 166-67, see also Merges, supra note 145, at 35-39.

${ }^{148}$ C.B. McPherson, Editor's Introduction to JoHn LOCKE, SECOND TREATISE OF Government vii, xvii (C.B. Macpherson ed., Hackett Pub. Co. 1980) (1690); JoHn Locke, SECOND TREATISE OF GOVERnMENT 56 (C.B. Macpherson ed., Hackett Pub. Co. 1980) (1690).

${ }^{149}$ See Shiffrin, supra note 142.

${ }^{150}$ Jonathan Peterson, Lockean Property and Literary Works, 14 LEGAL THEORY 257, 269 (2008).

${ }^{151}$ See Lemley, supra note 133, at 135; Pamela Samuelson, Should Economics Play a Role in Copyright Law and Policy?, (2003-2004) 1 U. Ottawa. L \& Tech. J. 3, 7 (2004); Litman, supra note 72; Shiffrin, supra note 142; LAWRENCE LESSIG, CODE: VERSION 2.0 (2006).

${ }^{152}$ See Landes \& Posner, supra note 146, at 326. 
order to achieve this, they argue that the law must recognize limited monopoly rights in creations and enable creators to recoup their investments. ${ }^{153}$ These assumptions underpinned legislation as early as the first modern copyright act, the Statute of Anne in 1709. ${ }^{154}$ Furthermore, the U.S. Constitution explicitly based its copyright and patent regimes on utilitarian foundations. ${ }^{155}$

Utilitarian theory often develops on the notion of free riding and the aforementioned tragedy of the commons. ${ }^{156}$ Free riding disables the creator from internalizing the full benefits of their creations, resulting in underinvestment. ${ }^{157}$ If intellectual property protection were not awarded, those who did not create could still enjoy the benefits. The creators, on the other hand, would be unable to recover the investments, efforts and costs they incur in the process of creating and innovating. ${ }^{158}$ Consequently, no creators would invest in creating. ${ }^{159}$ Thus, intellectual property protection eliminates this phenomenon, increasing the production of socially valuable intellectual property. ${ }^{160}$

How much intellectual property protection to afford, however, is up for debate. Landes and Posner recognize the central aim of copyright law as striking a balance between public and private interests. ${ }^{161}$ This balance is struck when net welfare is maximized, resulting in "the greatest good for the greatest number." ${ }^{162}$ For example, in the context of copyright, this means that intellectual property rules should be geared to "maximize the benefits from creating additional works minus both the losses from limiting access and the costs of administering copyright protection."163 Again, intellectual property achieves this by allowing the creator to internalizing positive externalities. ${ }^{164}$ But some scholars maintain that

${ }^{153} \mathrm{Id}$.

${ }^{154}$ Statute of Anne, 8 Ann., c. 19, 1710, (Gr. Brit.).

${ }^{155}$ U.S. Const. art I, $\S$ VIII, cl. 8. states that the purpose of protecting IP rights is "to promote the Progress of Science and useful Arts." As Samuelson observes: "[t]he principal justification for intellectual property law in the Anglo-American tradition is economic. Without a grant of exclusive rights, innovators would have too little incentive to invest in socially beneficial innovations ..." Samuelson, supra note 151.

156 See supra note 146.

157 See id.

${ }^{158} I d$. at 353-54.

${ }^{159}$ For a commentary, see Lemley, supra note 133, at 12.

${ }^{160} I d$.

${ }^{161}$ Landes \& Posner, supra note 146, at 326.

162 JEREMY BENTHAM, AN INTRODUCTION TO THE PRINCIPLES OF MORALS AND LEGislation 12-13 (J.H. Burns \& H.L.A. Hart eds., Athlone Press 1970) (1789).

${ }^{163}$ Landes \& Posner, supra note 146.

164 This issues prevents the positive externalities to be enjoyed by the public. Id. 
positive externalities are impossible to internalize, and that at any rate, consumption of creative outputs by many is desirable, as it enriches society and culture. ${ }^{165}$ Therefore, as the scholar Lemley states, "[I]f 'free riding' means merely obtaining a benefit from another's investment, the law does not, cannot, and should not prohibit it."166

Other opponents of using an exclusionary property right find that it is incomplete in striking an appropriate balance between private and public in the copyright context. ${ }^{167}$ The problem in these justifications for copyright, as scholars Boyle or Zemer would argue, is that they emphasize the property component as a precondition for incentivizing creation, thus disregarding the role of the public domain ${ }^{168}$ or the self-interested motivation for creation without legal incentives. ${ }^{169}$

In addition, critics deny that intellectual property protection is always necessary to recover the cost of innovation. ${ }^{170}$ This claim mainly relates to patents, as they are understood to require the highest level of investment in relation to other intellectual property rights. ${ }^{171}$ To support this argument, critics present the examples of innovations that are actually hard to copy or reverse engineer, such as integrated circuits and hardware protected by obfuscation techniques. In addition, some innovators recoup profits by keeping them secret. Other inventors may distribute products in a way that is expensive to replicate, as is the case in motion pictures on film stock or encrypting data. Finally, in a constant circle of innovation, there is a phenomenon where first movers are able to recoup costs, as happens in news, fashion, and trade secrets. ${ }^{172}$

Although utilitarian arguments could be used to justify propertization of information like trade secrets, they are weak

${ }^{165} \mathrm{Id}$. at 56

${ }^{166} I d$. at 24; see ALEXANDER \& PEÑALVER, supra note 143, at 184.

${ }^{167}$ See Lior Zemer, On the Value of Copyright Theory, 1 I.P.Q. 55, 55-71 (2006); Lemley, supra note 133, at 1066-67.

168 See James Boyle, Shamans, Software \& SpleEns: Law AND the CONSTRUCTION OF THE INFORMATION SOCIETY 244 (1996).

169 See Seana Valentine Shiffrin, The Incentives Argument for Intellectual Property Protection, 4 J.L. PHIL. \& CultuRE 49, 50 (2009) (observing that there is no solid evidence and research in the direction that granting IP for a certain period of time is "in fact necessary to incent creative production" and people do create even without these incentives).

${ }^{170}$ See id. at 51, 57.

${ }^{171}$ See Landes \& Posner, supra note 146, at 350.

172 See AleXANDER \& PeÑAlVER, supra note 143, at 188; Wesley M. Cohen, Richard R. Nelson \& John P. Walsh, Protecting Their Intellectual Assets: Appropriability Conditions and Why U.S. Manufacturing Firms Patent (or Not) 13 (Nat'l Bureau of Econ. Research, Working Paper No. 7552, 2000). 
justifications for the propertization of information on the whole. This approach especially fails with online and digital information, where incentives are not needed where information overload exists. ${ }^{173}$ This approach ultimately fails, however, because internalizing positive externalities to a great extent should be avoided.

\section{Personhood Theories}

Personhood theories for intellectual property represent a strong alternative to the previous theories. They emphasize a personal, nonpecuniary version of intellectual property, concluding that intellectual creation is an expression of one's self. ${ }^{174}$ Discussing whether ideas and creations can be considered things and property, the philosopher Hegel notes they can be contracted, but they are something inward and mental. Thus, Hegel implies it is hard to describe ideas in legal terms. ${ }^{175}$ Although primarily mental, Hegel concludes that "by expressing them it may embody them and in this way they are put in the category of "things." "176 Hughes in particular finds this theory appealing, noting that "the Hegelian personality theory applies more easily because intellectual products, even the most technical, seem to result from the individual's mental processes." 177

One of the most prominent personhood theories based on Hegelian arguments has been put forth by Radin. This theory divides property into fungible and personal categories and asserts that "the more closely connected with personhood, the stronger the entitlement." ${ }^{178}$ This provides powerful grounds for strong intellectual property protection. The problem here, however, relates to alienability of creative works. Whether an author can restrict further communication of her work must be determined, as does the issue over whether it remains within her "personhood." 179 Indeed, authors may have a strong interest in the continuing control over their

173 See, e.g., Martin J. Eppler \& Jeanne Mengis, The Concept of Information Overload: A Review of Literature from Organization Science, Accounting, Marketing, MIS, and Related Disciplines, 20 THE INFO. SOC'Y 325, 325-44 (2004); Troy A. Peredes, Blinded by the Light: Information Overload and Its Consequences for Securities Regulation, 81 WASH. U. L. Q. 417, 417-86 (2003). ${ }^{174}$ See Hughes, supra note 142, at 330 ("[A]n idea belongs to its creator because the idea is a manifestation of the creator's personality or self.").

175 See GeORg Wilhelm Friedrich Hegel, Hegel's PhILOSOPHY OF Right II 38 (T.M. Knox trans., Oxford Univ. Press 1967).

${ }^{176} \mathrm{Id}$.

${ }^{177}$ Hughes, supra note 142, at 365.

${ }^{178}$ Margaret Jane Radin, Property and Personhood, 34 STAN. L. REV. 957, 986 (1982).

${ }^{179}$ William Fisher, Theories of Intellectual Property, in NEW ESSAYS IN THE LEGAL AND POLITICAL THEORY OF PROPERTY 190 (Stephen R. Munzer ed., 2007). 
expression, ${ }^{180}$ but the expression itself may in fact "[c]ommodify what was declared uncommodifiable." ${ }^{181}$ This question of alienability must be answered before the proper intellectual property protections are determined, for Hegel says nothing about whether intellectual property should be protected. Hegel simply claims that, if society adopts such a regime based in personhood, it is coherent to formulate it in terms of true property rather than some sui generis rights. ${ }^{182}$

Personhood theory is applicable to information to an extent. However, because of their non-personal, commercial character, some kinds of information (such as trade secrets and fresh news) cannot be justified under this theory. In contrast, other information (such as personal data that is intrinsically tied to an individual) can perhaps find better support under this approach.

After evaluating these three theories of property and their connection to email-information, none of them are sufficient. Thus, the non-copyrightable content of emails, information, and personal data is not and should not be considered property.

\section{CONCLUSION}

Based upon current copyright and property law, and upon the western theories of property, the legal nature of email appears clear. Email content is not the property of its users. It can, however, be protected by copyright, the tort of misuse of confidential information, trade secret doctrine, data protection, or publicity rights.

Thus, there is a conflict between the law and the market, in the form of service providers in their respective treatment of email. Laws give rights to users with respect to their email content only insofar as it falls under the aforementioned protections. This falls short of full ownership protection, exposing a potentially large and indeterminable proportion of email content. In contrast, the market and other actors support a different conclusion: that users own their own content just as they own tangible property. ${ }^{183}$ Ideally, legal harmonization should first occur between U.S.

180 Neil Netanel, Copyright Alienability Restrictions and the Enhancement of Author Autonomy: A Normative Evaluation, 24 RUTGERS L.J. 347, 400 (1993).

${ }^{181}$ Lloyd L. Weinreb, Copyright for Functional Expression, 111 HARV. L. REV. 1149, 1222 n.310 (1998).

182 See id. at 189.

${ }^{183}$ However, the account itself is not the property of the individual. The owner has a contractual right to use it but does not have a right to transfer it and the account remains the property of the service provider. See Google Terms of Service, GoOGLE (Apr. 14, 2014), http://www.google.com/int//enGB/policies/terms/ ("Using our Services does not give you ownership of any intellectual property rights in our Services or the content that you access. You 
and U.K. legal regimes to rectify the slight differences in approach to the legal nature of email content. Harmonization should then occur between the legal and market systems, for it would clarify the legal consensus and enable more coherent market approaches to technology. More specific suggestion in this regard, as well as the relationship between legal nature of emails and their transmission upon death, will be explored in the author's future publications.

may not use content from our Services unless you obtain permission from its owner or are otherwise permitted by law. These terms do not grant you the right to use any branding or logos used in our Services. Don't remove, obscure or alter any legal notices displayed in or along with our Services."); Microsoft Services Agreement, MicRosofT II 4.a.i. (June 4, 2015), https://www.microsoft.com/enus/servicesagreement/; see also Jim Lamm, Planning Ahead for Access to Contents of a Decedent's Online Accounts, Digital PASsing (Feb. 9, 2012), http://www.digitalpassing.com/2012/02/09/planning-ahead-access-contentsdecedent-online-accounts/. 